\title{
Lowest Value Principle Implementation in Inventory Measurement of Financial Statements of the Enterprises
}

\author{
Kulikova L.I.a \\ Sokolov A.Y.b \\ Ivanovskaya A.V.c \\ Akhmedzyanova F.N.d \\ a bcd Kazan Federal University, Institute of Management, Economics and Finance, Kazan, 420008, Russia \\ Email: anna_ivanovski@mail.ru
}

\section{Doi:10.5901/mjss.2015.v6n1s3p406}

\section{Abstract}

The article explores an issue of implementing of material and production inventories measurement at lowest value in accounting practices for the purpose of drawing up financial statements. A comparison is made in terms of approach to the lowest value principle implementation in accordance with American, Russian and international accounting standards. For the first time, a methodology for calculating of allowance for impairment of inventory based on specific features of enterprise's activities is being considered. Given in detail is a description of development stages of allowance for impairment of inventory based on specific procedures carried out.

Keywords: inventories, measurement, allowance, impairment, US GAAP, IAS 2

\section{Introduction}

Many accounting standards, regulating the procedure of inventory measurement, take the lowest value principle as the most well-grounded method of inventory measurement when drawing up financial statements. The main merit of the given principle is that financial statements should not state obsolete inventories and those that lost their original quality at actual cost of acquisition. The above-noted inventories are stated at the market value. Allowance for impairment of inventory is formed for the given purposes. However, there are no particular techniques for establishing of allowance for impairment of inventory in current legislation and accounting regulations in present-day Russia. In our research, we have developed approaches to establishing of allowance for impairment of inventory by means of particular procedures introduced in stages. This helps to compile information on inventory cost for financial statements.

\section{Method}

Application of the lowest value principle for inventory measurement has a long history. As noted by American economists Hendriksen, Eldon S. and M.F. Breda, the given principle was in use in the XIX century and even earlier, when the significance of balance sheet as a report to creditors was determined. In the absence of reported data for making forecasts on investment of funds, creditors paid special attention to the minimum probable value of assets in circulation [1].

The issue of inventory measurement for the purpose of reporting it in financial statements is addressed in the studies of Milbradt, K. [2], Liapis, K.J. and E.P. Christodoulopoulou [3], Easton, P. and J. Pae [4], Liapis, K.J. and C.L. Galanos [5].

In practice, it may be possibe that the cost of inventories is not recoverable. The reasons for that are as follows: damage, total or partial obsolescence, reduction of inventory selling price, increase in eventual costs for completion of inventory production, increase in eventual costs to sell. In such circumstances, the carrying amount of inventories should be adjusted downwards in financial statements preparation. That is the essence of the lowest value principle [6].

In the present time, the above-mentioned principle applied for inventory measurements is widely used for financial statements drawing up in accordance with international standards. As per IAS 2 "Inventories" inventories should be 
measured at the lower of cost and net realizable value. Net realizable value is the estimated selling price in the ordinary course of business less the estimated costs of completion and the estimated costs necessary to make the sale. This value is determined in each particular enetrprise. If inventories are meant for sale, then net realizable value is determined based on current market prices. Net realizable value of inventories intended for sale as per sale contracts is based on the contract price [7].

The specifics of inventories measurement in accordance with American accounting standards are reflected in the works of Needles, B.E., Anderson H.R. and J.C. Caldwell [8], Larson, K.D. and P. Miller [9], Meigs, R.F., Meigs W.B. and M.A. Meigs [10]. US GAAP uses market value, which is current replacement cost, for inventory valuation. That is the cost that can be paid by the enterprise for similar inventories in active market conditions and sufficient awareness of a seller and a customer under no coercion. If the reduction of replacement cost does not reflect the decrease in inventories utility then two additional cost limits are used: upper limit (net realizable value) and lower limit (net realizable value less normal profit margin). Setting of upper limit when determining replacement cost prevents from overvaluing obsolete, damaged or slow-moving inventories. Setting of the lower limit restrains inventory cost reduction and loss increase in the current period [11]. Unlike US GAAP, international standards do not use upper and lower limits to determine market value.

Allowance for impairment of inventories is somehow similar to lower value principle for inventory measurement in Russian accounting. In accordance with Balance sheet principles approved in USSR in 1928, it was obligatory to set up impairment allowance. Known Russian balance issues researcher N.A. Blatov described the procedure of allowance development in the following way: "Impairment allowance is set up for the difference between the book value of products and finished goods and their value at lower market or regulating authorities' prices. Bringing products and finished goods to measurement at a lower price, recognized by the legislation as real, the given allowance imposes onto the current year the loss that appears possible for the future year at the moment accounts are balanced" [12].

Based on the currently enforced Russian Accounting Regulation "Inventories accounting" (RAR 5/01), as of the end of the reporting year, enterprises form the mentioned allowance for the amount of prevalence of the actual cost of inventories over their current market value. Thus, "the lowest price" principle is also declared in the Russian accounting in regard to inventories.

It should be noted that impairment allowance raises many questions in the course of practical activities of Russian enterprises and, in the first place, that is due to the difficulty in determining the real amounts.

Allowance should be formed for each inventory unit recognized in accounting, or for separate types (groups) of similar or adjacent inventories. As per RAR 5/01 inventories include: materials, products and finished goods.

At the time, N.A. Blatov thought that "the lowest price" principle should be used only for the products and finished goods but not for materials and semi-finished products, since only "sales of products and finished goods could give that losses for covering of which allowance is formed" [12].

We believe that the lowest price principle could not be applied to all inventories but only to finished goods and products with established selling prices. Forming of impairment allowance for raw materials, materials, semi-finished products, etc. without conducting of thorough analysis of the influence of impairment on the possible market value of finished goods allows entities to manipulate balance sheet indicators.

The application of the lowest price principle to the inventories leads to the problem of confirming of current market value of the inventories. Consideration should be given to the price fluctuations related to the events taking place after the reporting date and confirming conditions existing at the end of the reporting period, as well as the purpose of inventories.

In 1926, I.R. Nikolaev spoke about the problem of market value setting for inventories and their disclosure in the balance sheet. He believed that the difficulty in the application of market (exchange) value is in the fact that not all the products are traded at exchange, for example, handicraft ware. Market values cannot be applied to many semi-finished products, as well as to the goods that were exposed to spoilage and lost the significant part of their value. All such products can't be quoted and their "actual" value cannot be determined [13].

Existing rules of allowance forming for impairment, specified in Russian regulatory documents, give rise to a series of questions. How to determine the obsolescence of inventories and the loss of their initial qualities? How to confirm the calculation of current market value of inventories? Due to the uncertainties in regulations, many Russian companies do not form the mentioned allowance, thus overrating inventories, recognized in the balance sheet, as well as the profit in the reporting period.

\section{Result}

Allowance for impairment of inventories is the imputation of inventory impairment roughly determined or calculated based on accounting assumption in the absence of precise way of its determination [14, 15]. 
Forming of allowance for impairment of materials has some peculiarities compared to forming of allowance for impairment of finished goods and products. That is shown in figures 1 and 2.

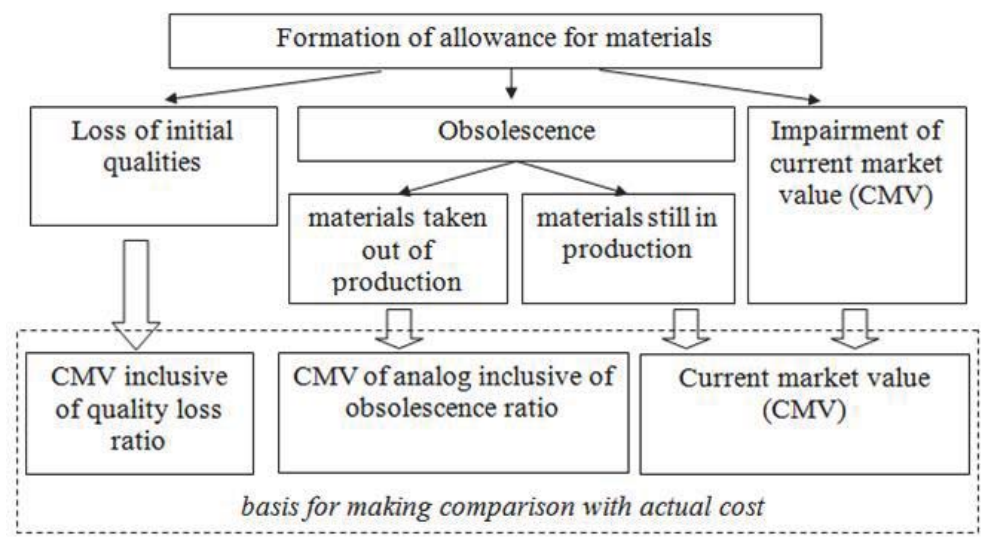

Fig. 1. Peculiarities of formation of allowance for materials

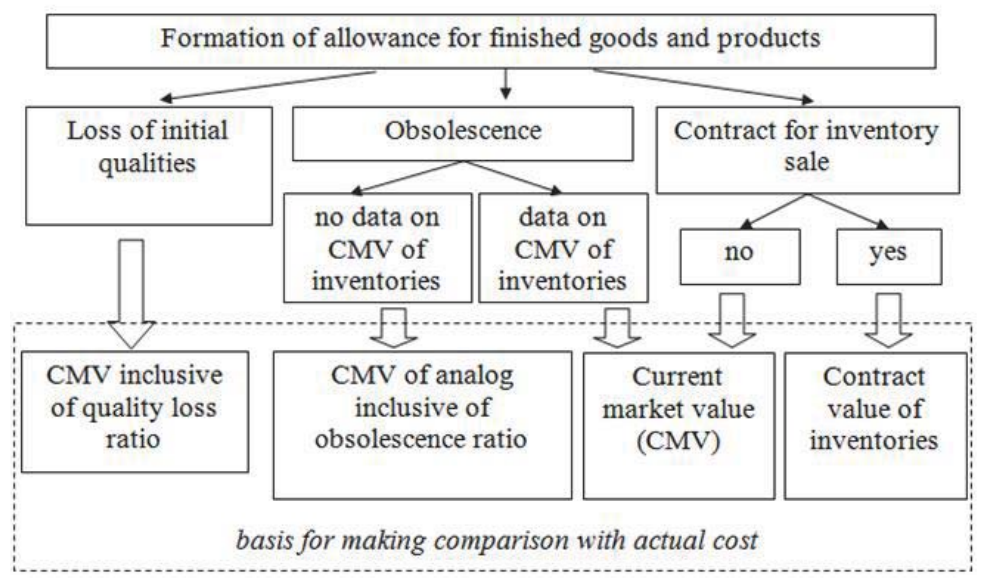

Fig. 2. Peculiarities of formation of allowance for finished goods and products

We believe that formation of allowance technique suggests carrying out particular procedures comprising a number of stages.

Stage 1. Setting inventory accounting unit for the purpose of allowance formation based on specific activities of the enterprise. That unit could be represented by a homogeneous group of inventories (for example, plug fittings, bobbins, polypropylene, ethylene, etc.)

Stage 2. Taking annual inventory before the preparation of financial statements and identification of inventories, purchased not less than 1 year before stocktaking.

Stage 3. Selection of essential groups of inventories. Groups of inventories the value of which at the date of stocktaking is more than $1 \%$ of the total inventory value are recognized essential. Inessential groups of inventories are not analyzed any further.

Stage 4. Documentary evidence of the current market value for inventories, having initial quality characteristics and not being obsolete, based on the information available before the date of signing financial statements [16]. The following information can be used: quotations, online trading, vendors' catalogues, dealers' catalogues, etc. In the absence of information on the current values for similar products on the market, the actual cost of inventories is recognized equal to the market value in accordance with accounting data if the following conditions are fulfilled simultaneously: inventory is unique, it has initial qualitative characteristics and is suitable for production activity [17].

Stage 5. Calculation of current market value (CMV) for inventories that lost their initial qualitative characteristics and are obsolete, taking into account matching ratio of the inventories and their initial quality and obsolescence using the 
formula:

$\mathrm{CMV}=\mathrm{CMV}_{\mathrm{a}} \times \mathrm{K}_{1} \times \mathrm{K}_{2}$

where $\mathrm{CMV}_{\mathrm{a}}$ - current market value of similar inventories, having initial qualitative characteristics and not obsolete;

$\mathrm{K}_{1}-$ matching coefficient for inventories and their initial quality;

$\mathrm{K}_{2}$ - inventories obsolescence coefficient.

The scale presented in table 1 is used to determine coefficients $K_{1}$ and $K_{2}$.

Table 1. The scale of coefficients $K_{1}$ and $K_{2}$

\begin{tabular}{|c|c|}
\hline Inventories characteristics & Value \\
\hline \multicolumn{2}{|l|}{ Matching coefficient for inventories and their initial quality $\left(\mathrm{K}_{1}\right)$} \\
\hline $\begin{array}{l}\text { Inventories are not suitable for use as intended, no possibility to bring them to usable condition, but } \\
\text { they can be used for the purposes not connected with their immediate purpose }\end{array}$ & $0.3-0.4$ \\
\hline $\begin{array}{l}\text { Inventories are not suitable for use as intended, but it is possible to bring them to usable condition } \\
\text { without significant costs }\end{array}$ & $0.41-0.60$ \\
\hline Inventories partially lost their initial qualitative characteristics but are suitable for use as intended & $0.61-0.80$ \\
\hline $\begin{array}{l}\text { Inventories are suitable for use as intended but there could be slight changes in their appearance, } \\
\text { not influencing use effectiveness }\end{array}$ & $0.81-1$ \\
\hline \multicolumn{2}{|l|}{ Inventories obsolescence coefficient $\left(K_{2}\right)$} \\
\hline Specified type of inventories is taken out of production but can be used in production activity & $0.1-0.6$ \\
\hline Specified type of inventories is still in production but with slight functional improvements & $0.61-0.90$ \\
\hline $\begin{array}{l}\text { Non-obsolete inventories, as well as inventories, output volume of which is significantly reduced due } \\
\text { to more improved inventories on the market }\end{array}$ & $0.91-1$ \\
\hline
\end{tabular}

Stage 6. Comparing of current market value of inventories to actual cost and deviations determining (D):

$\mathrm{D}=\mathrm{C}-\mathrm{CMV}$ where $\mathrm{C}$ - actual cost of inventory.

Stage 7. Setting of materiality level for deviations of current market value of inventories to their cost. Materiality level could be set at $10 \%$ of the cost of inventories.

Stage 8. Making a decision on allowance formation. Allowance for impairment is not formed for inventories, if on the reporting date their current market value equals to cost or increases it, e.i. $D \leq 0$. Only those deviation sums that are considered essential are included in allowance calculations.

Materials are additionally scrutinized: allowance is not formed for materials if they are included in finished products that are planned to be sold at a price not lower of the cost.

Stage 9. Determining of the sum of allowance for impairment. The example of calculating the sum of allowance for impairment of separate type of materials is shown in table 2 .

Table 2. Calculation of allowance for impairment of materials

\begin{tabular}{|c|c|}
\hline Indicators & Value \\
\hline 1. Cost of inventory, rub. (C) & 5000 \\
\hline $\begin{array}{l}\text { 2. Current market value of similar inventories, having initial qualitative characteristics } \\
\text { and not obsolete, rub. }\left(\mathrm{CMV}_{\mathrm{a}}\right)\end{array}$ & 4000 \\
\hline 3. Matching coefficient for inventories and their initial quality $\left(\mathrm{K}_{1}\right)$ & 0.61 \\
\hline 4. Inventories obsolescence coefficient $\left(K_{2}\right)$ & 0.5 \\
\hline 5. Current market value of inventories, rub. (CMV $\left.=\mathrm{CMV}_{\mathrm{a}} \times \mathrm{K}_{1} \times \mathrm{K}_{2}\right)$ & 1220 \\
\hline 6. Deviation of inventory cost from current market value, rub. (D = C - CMV) & 3780 \\
\hline 7. Materiality level of deviation, rub. (ML=Cx10\%) & 500 \\
\hline $\begin{array}{l}\text { 8. Deviation, accepted for calculation of allowance for impairment of inventories, rub. } \\
(D r=D \text {, if } D>0 \text { and } D>M L \text {, otherwise } D r=0)\end{array}$ & 3780 \\
\hline
\end{tabular}

\section{Conclusion}

Calculation methodology for allowance impairment of inventories offered by us allows implementing of the principle of the 
lower value. That is necessary for both internal monitoring of inventories that are obsolete and lost their initial quality, and for revealing of information on enterprise's inventories in financial statements. Formation of allowance for impairment of inventories should be done based on the assessment of the current state of business and expected future gains from utilization of inventories.

\section{References}

Hendriksen, E.S., Breda, M.F. Accounting Theory. Homewood: Irwin, 1992. 905p.

Milbradt, K. Level 3 assets: Booking profits and concealing losses // Review of Financial Studies 25 (1), 2012. pp. 55-95.

Liapis, K.J., Christodoulopoulou, E.P. How GAAP and accounting treatments influence property management // Journal of Property Investment and Finance 29 (3), 2011. pp. 251-279.

Easton, P., Pae, J. Accounting conservatism and the relation between returns and accounting data // Review of Accounting Studies 9 (4), 2004. pp. 495-521.

Liapis, K.J., Galanos, C.L. Accounting GAAPs and accounting treatments for management of property: Case studies from Greek Real Estate Market // European Research Studies Journal 13 (3), 2010. pp. 169-194.

Kulikova, L.I., Goshunova, A.V. Efficiency measurement of professional football clubs: A non-parametric approach // Life Science Journal 11 (SPEC. ISSUE 11), 2014. pp. 117-122.

Kulikova, L.I., Goshunova, A.V. Measuring efficiency of professional football club in contemporary researches // World Applied Sciences Journal 25 (2), 2013. pp. 247-257.

Needles, B.E., Anderson H.R., Caldwell J.C. Principles of Accounting. 4th ed. Houghton Mifflin Company, 1990. 1220p.

Larson, K.D., Miller, P.B. Fundamental Accounting Principles. 13th ed. Homewood; Boston: IRWIN, 1999. 1136 p.

Meigs, R.F., Meigs, W.B., Meigs, M.A. Financial Accounting. 8th ed. New York etc. McGraw-Hill, 1995. 846 p.

Needles, B.E., Powers M. Principles of financial accounting. 10th ed. New York Houghton Mifflin Company, 2008. 858 p.

Blatov, N.A. Science of balance preparation (general course). State Trade Publishing House, Russia, 1931. 320 p.

Nikolaev, I.R. The problems of the reality of the balance sheet. Publishing house «Economy of economic education», Russia, 1926. 109 p.

Kulikova, L.I. Formation of valuation allowances // Financial herald 5, 2011. pp. 70-79.

Kulikova L.I., Goshunova A.V. Human Capital Accounting in Professional Sport: Evidence from Youth Professional Football /I Mediterranean Journal of Social Sciences 5(24), 2014. pp. 44-48.

Kulikova L.I., Gubaidullina A.R., Arzhantseva N.V. The Need of Professional Judgement of the Accountant in Accounting Assets of Exploration and Evaluation of Mineral Resources // Mediterranean Journal of Social Sciences 5(24), 2014. pp. 65-69.

Kulikova L.I., Gafieva G.M. Falsification of Financial Statements: Historical and Evolutionary Aspect // Mediterranean Journal of Social Sciences 5(24), 2014. pp. 41-43. 